\title{
Geomorphology and Glacial Geology of the Martin River Glacier, Alaska
}

\author{
JOHN R. REID, JR. ${ }^{1}$
}

\begin{abstract}
The terminal $17 \mathrm{~km}$. of the Martin River Glacier, and its periphery offer a unique insight into a dynamic system involving land forms, water, plants and animals, all of which are directly dependent upon the glacier regimen. Of the four zones, the Active Ice, Intermediate, Terminal, and Glaciated, the first is the most extensive. The second two are characterized by forest and brush-covered superglacial drift, less than $1 \mathrm{~m}$. to more than $3 \mathrm{~m}$. in thickness. Ice sinkhole depressions and lakes are common and may drain suddenly via englacial and subglacial channels. Occasional clear lakes are present in the Terminal Zone where ice may lie beneath only 1 to $2 \mathrm{~m}$. of superglacial drift, which is sufficient to protect the lake water from the cold ice and allow successful propagation of aquatic fauna. Trees in the Terminal Zone indicate that this zone was glacially active about A.D. 1650 . The outermost terminal moraine and the numerous moraine segments in the Glaciated Zone are probably of Late Wisconsin age. These can be traced to the upper 14 lateral moraines in the valley of the Charlotte Lobe. The soils in the lower 7 moraines are immature to azonal and are probably of Neoglacial age.
\end{abstract}

RÉSUMÉ. Géomorphologie et géologie glaciaire du glacier de la rivière Martin, Alaska. Les derniers $17 \mathrm{~km}$ du glacier de la rivière Martin et leur voisinage offrent un aperçu unique sur un système dynamique groupant formes de terrain, eau, plantes et animaux, tous dépendants du régime du glacier. Des quatre zones: zone de glace active, zone intermédiaire, zone terminale et zone glaciée, la première est la plus étendue. Les deux suivantes se caractérisent par de la moraine de surface, d'une épaisseur variant de moins d'un mètre à plus de 3 mètres, couverte de forêt et de broussailles. Lacs et dépressions de fonte sont communs et plusieurs se drainent soudainement par des chenaux "englaciaires" et sous-glaciaires. Quelques lacs sont présents dans la zone terminale où la glace se trouve sous de 1 à $2 \mathrm{~m}$ seulement de moraine de surface, ce qui est suffisant pour protéger les eaux lacustres de la glace et permettre la propagation de la faune aquatique. Les arbres de la zone terminale indiquent que cette zone était glaciairement active vers l'an 1650. La moraine terminale extérieure et les nombreux segments de moraine de la zone englacée sont probablement d'âge fini-wisconsinien. On peut les relier aux 14 moraines latérales supérieures de la vallée du lobe Charlotte. Les sols des 7 moraines inférieures vont de "l'immature" à "l'azonal" et sont probablement d'âge néo-glaciaire.

РЕЗЮМЕ. Геоморфология и геолоеил ледника Мартин Ривер (Аляска). Последние 17 км ледника Мартин Ривер и его краевал часть предоставляют исключительную возможность изучить комплексную динамическую систему, включающую в себе различные формы рельефа, водные потоки и водоемы, растительный покров и животных, и находящуюея в прямой зависимости от ледникового режима. Дается описание четырех ледниковых вон : зоны активного льда, промежуточной зоны, конечной зоны и зоны оледенения. Наиболее обтирной является зона активного льда. Отличительной чертой промежуточной п конечной зон является наличие ледниковых наносов мощностью до 3 м, покрытых лесом и кустарниками. Многочисленные овера, встречающиеся в этих зонах, нередко исчезают вследствие ухода воды по внутриледниковым и подледным протокам. Отдельные прозрачные озера встречаются в конечной воне, где лед иногда валегает под слоем наносов мощностью липь 1-2 м, чего, однако, достаточно для предохранения воды от охлаждающего әффекта льда и развития водной фауны. Высказывается предположение, что конечная морена и многочисленные сегменты морен в зоне оледенения образовались в поздневисконсинский период.

1 Department of Geology, University of North Dakota, Grand Forks, N.D. 


\section{INTRODUCTION}

\section{Location}

The Martin River Glacier is located in south-central Alaska between $143^{\circ} 21^{\prime} \mathrm{W}$. and $144^{\circ} 19^{\prime} \mathrm{W}$., $60^{\circ} 37^{\prime} \mathrm{N}$. and $60^{\circ} 28^{\prime} \mathrm{N}$. (Fig. 1). The nearest town, Cordova, is approximately $96 \mathrm{~km}$. west of the glacier terminus, and the site of the former town of Katalla lies at the shore of Controller Bay, about $30 \mathrm{~km}$. south (U.S. Geological Survey, Cordova and Bering Glacier sheets, 1:250,000). The terminal area of the glacier is included on the U.S. Geological Survey, Cordova B-1 and C-1 Quadrangles.

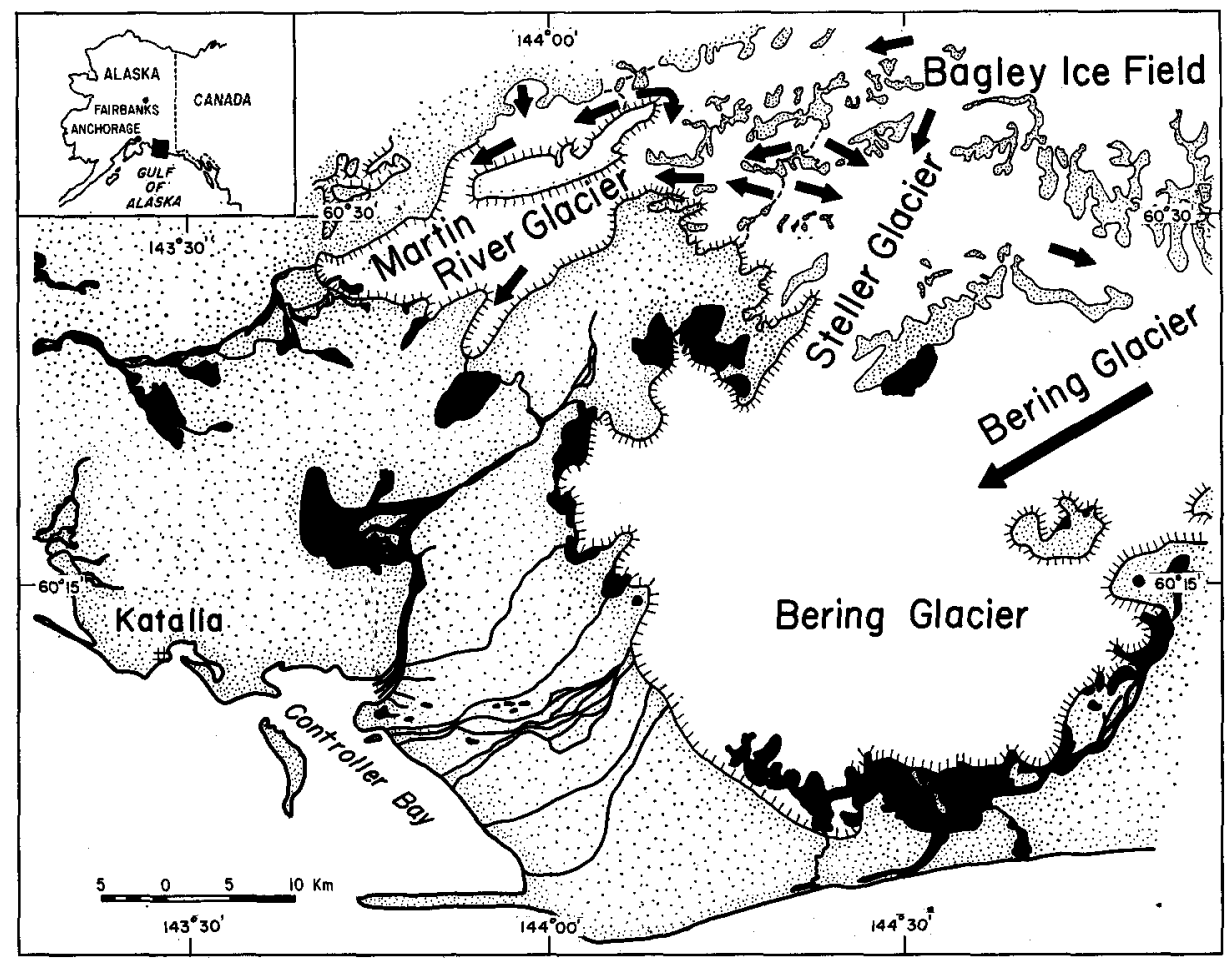

FIG. 1. Location of Martin River Glacier and relationship to the Bering and Steller Glaciers. Arrows mark ice flow directions.

\section{Environment}

The Martin River Glacier originates at 1,200 m. elevation at the western margin of the Bagley Ice Field in the Kenai-Chugach mountains division of the Pacific Border Ranges physiographic province, and it terminates at $120 \mathrm{~m}$. elevation in the Gulf of Alaska Coastal Section (Wahrhaftig 1965, p. 40). The Bagley Ice Field is the centre of accumulation for several glaciers, including the Bering Glacier, south and east of the Martin River Glacier.

The climate of the terminal area is cool maritime; the average annual temperature since 1920 has been about $4^{\circ} \mathrm{C}$. and the average annual precipitation has been about $300 \mathrm{~cm}$. (Fig. 2). Although the weather data were collected at Cordova, they probably approximate conditions in the area of the Martin River 


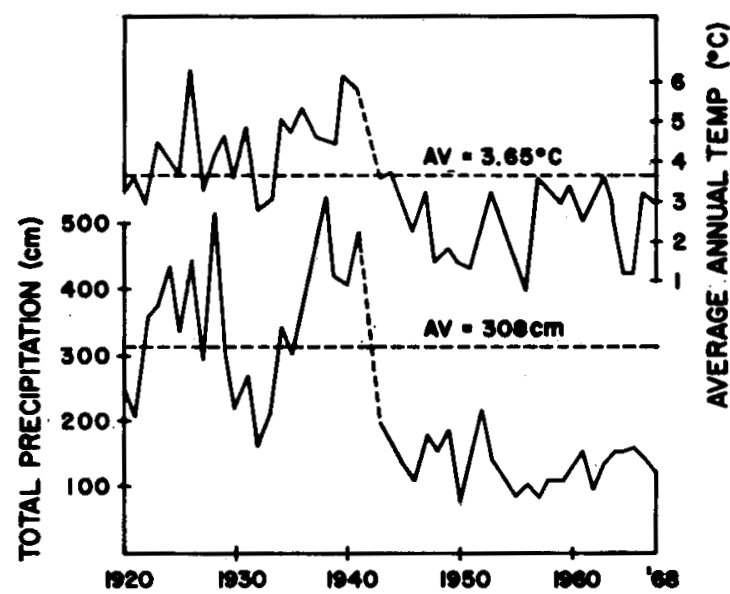

FIG. 2. Average annual precipitation and temperature for Cordova, Alaska, since 1920.

Glacier. But because the terminal area of the glacier is bounded by the mountains, both higher precipitation and lower temperatures are probable.

Except for a period of about five years (1928 to 1933), the weather before 1942 was warmer and wetter than since that time. The data also show a general direct correlation between annual temperature and annual precipitation, except that the reverse appears to be true when comparing temperatures and precipitation for the growing season; those years with a high summer precipitation had a low temperature, presumably because of more cloudy days.

The vegetation of the area is strongly influenced by the elevation; the lowlands are characterized by luxuriant growth of a variety of trees, shrubs and ground cover. K. B. Switzer (unpublished research, University of North Dakota) has determined that in the terminal areas of the Martin River Glacier and the Charlotte Lobe, alder (Alnus fruticosa), willow (Salix sp.), spruce (Picea sitchensis), and hemlock (Tsuga heterophylla) all begin growing on the deglaciated or dead ice terrain at about the same time. Alder quickly outgrows the other vegetation giving the illusion that only alder is present. In places, even on the glacier, alders are so thick that machetes are necessary to enable passage through the area. As the alders reach maturity and begin to die, the willow assumes the role of the most conspicuous vegetation. Spruce and hemlock continue to grow slowly and eventually the spruce becomes dominant, forcing out the alder and willow. These spruce trees reach heights of $25 \mathrm{~m}$. to $35 \mathrm{~m}$., and some exceed $2 \mathrm{~m}$. in diameter. The climax forest is hemlock, which is the dominant tree in the terminal moraine and on some of the lateral moraines between the Martin River and the Slide ("Sioux") glaciers (Fig. 3). The higher areas are characterized by a thick mat of alpine vegetation; trees are entirely absent.

\section{Geology}

The geology of the Martin River Glacier area is rather complex and not well known. The most recent and detailed compilation is by Plafker (1967). His map shows the Chugach-St. Elias. Fault trace extending along the axis of the lower part of the Martin River Glacier. This fault separates Mesozoic and older volcanic rocks on the north side (greenstone and slightly to moderately metamorphosed 


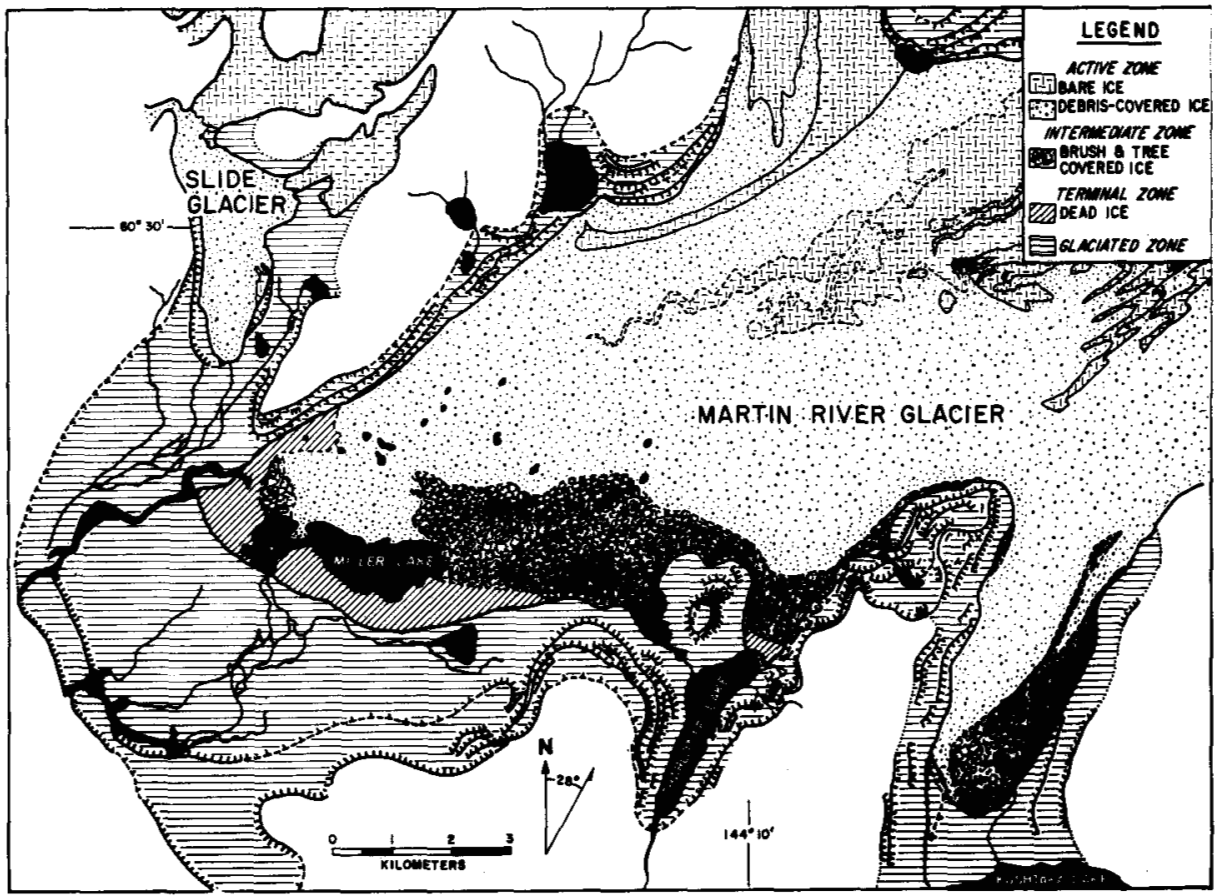

FIG. 3. Lower $15 \mathrm{~km}$. of Martin River Glacier showing distribution of zones. Hachured lines mark moraines.

graywacke) from Eocene and Oligocene marine and terrestrial rocks on the south (siltstones, sandstones, and coal). Marine fossils are present but not common in these Tertiary sediments.

A second fault parallels the Chugach-St. Elias Fault $2 \mathrm{~km}$. to $20 \mathrm{~km}$. farther north. This unnamed fault separates the slightly metamorphosed volcanics on the south from the moderately to highly metamorphosed crystalline rocks on the north (granitics, schists, gneiss, amphibolites and some marble). The fault cuts through Slide Glacier at right angles to its axis, approximately $1.5 \mathrm{~km}$. from its terminus (Plafker 1967). The superglacial debris on both glaciers reflects the sharp variation in lithology on each side of these faults (Fig. 4).

\section{Previous Glaciological Work}

Drift-covered glaciers have intrigued many geologists but most reports, including those of the Martin River Glacier, have been restricted to specific features or phenomena. An exception has been the investigations of the Malaspina Glacier (Hartshorn 1952; Plafker and Miller 1957) and the Wolf Creek Glacier (Sharp $1949,1951)$. Sharp's reports form the basis for comparison with the Martin River Glacier studies.

Except for the peripheral studies of Martin (1908) and Tarr and Martin (1914), and an engineering report by Kachadoorian (1960), very little was known about the Martin River Glacier until research was begun by the University of North Dakota in 1962 under the direction of Wilson M. Laird. The area was visited each 


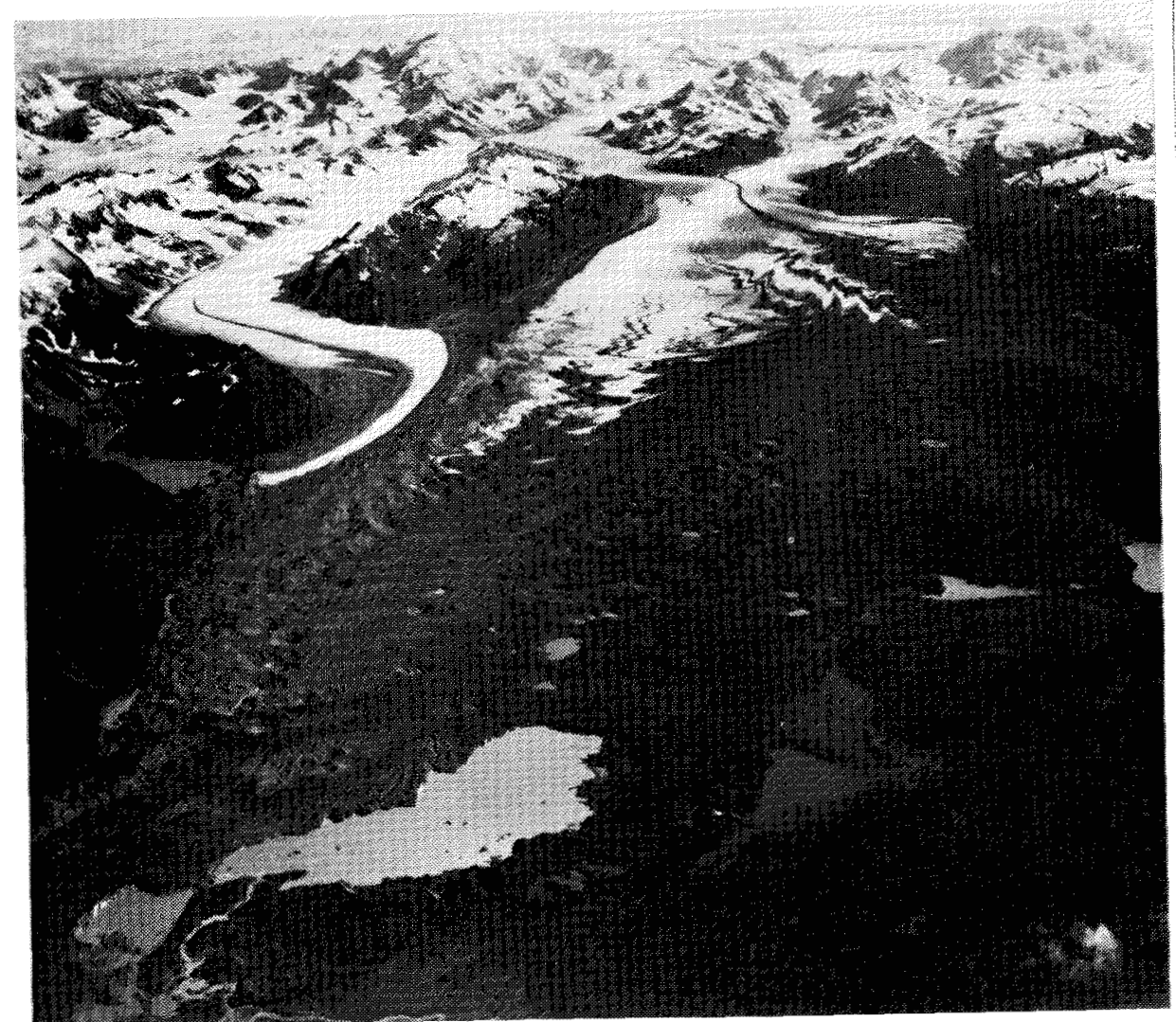

FIG. 4. Martin River Glacier, east from the terminus. "Miller Lake" is in foreground; tip of Charlotte Lake is along right margin. Note distribution of exposed and drift-veneered ice, deformed medial moraines, and ice sinkhole lakes (Photo by Austin Post, U.S. Geol. Survey, 1966).

summer from 1962 to 1966 and again in 1968. Laird was principal investigator for the 1962-63 expeditions when the emphasis was on geomorphology and ecology of the glacier environment. The present author was responsible for the 196566 and 1968 research projects when more specific studies on glacier regimen and glacial geology were completed. The 1964 project was the responsibility of Laird and S. J. Tuthill and the purpose was to evaluate the results of the Alaska earthquake. The results of all of these projects have been more fully summarized previously by Reid (1970).

The Great Alaska Earthquake of 1964 brought more outside attention to the Martin River Glacier and it was included in a number of reports on the effects of the earthquake (Grantz et al. 1964; Post 1965, 1967; Ragle et al. 1965). Although numerous papers have been written on specific aspects of the glacier by members of the Department of Geology at the University of North Dakota (see for example Clayton 1964; Reid 1969, 1970; Reid and Callender 1965; Reid and Clayton 1963; Tuthill 1963, 1969; and Tuthill and Laird 1966), a more complete report on the geomorphology of this glacier has not been attempted. 


\section{Present Investigations}

Because relatively little has been written about drift-veneered glaciers it seems useful to present a fairly detailed description of one. For biologists and physical geographers, as well as pedologists and geologists, the Martin River Glacier offers a view of a dynamic system in which climate, vegetation, fauna, hydrology and surface morphology are all interrelated, dependent upon the regimen of the glacier. The study becomes most significant when it is accepted that many terminal areas of the Pleistocene ice sheets were similar to the lower $17 \mathrm{~km}$. of the Martin River Glacier. Although most of this paper is descriptive it is hoped that the details offer a better insight into a drift-covered glacier.

\section{PHYSICAL CHARACTERISTICS OF THE GLACIER}

\section{Size and Shape}

The Martin River Glacier covers about $145 \mathrm{sq} . \mathrm{km}$. From its point of discharge from the Bagley Ice Field at an elevation of about 1,200 m. it flows $64 \mathrm{~km}$. down the steep front of the Chugach Mountains to an elevation of about $120 \mathrm{~m}$. There are numerous tributaries above the firn zone, but only one below. This unnamed tributary enters the glacier about $7 \mathrm{~km}$. from the terminus, but does not appear to contribute much to the main glacier (see Fig. 1).

The widest part of the Martin River Glacier, $8 \mathrm{~km}$., is approximately $14 \mathrm{~km}$. from the terminus; it probably averages about $2 \mathrm{~km}$. in width. The shape of this lower part of the glacier gives it the characteristics of an expanded-foot glacier, i.e. spreading of the glacier into the Martin River valley, at the foot of the Chugach Mountains, identifies this as a special type of a foot glacier, but not quite a piedmont glacier.

Several lobes have formed where the ice has flowed through saddles in the Tertiary hills along the south side of the glacier. The largest of these is the Kushtaka Lobe (Fig. 3), which terminates in a delta at the head of Kushtaka Lake, and which recently was described briefly by Stephens (1969). The second lobe is the Charlotte Lobe, which is separated from the Kushtaka Lobe by Charlotte Ridge, a $730 \mathrm{~m}$.-high moraine-draped ridge. Charlotte Lobe terminates in a delta at the head of Charlotte Lake.

\section{Surface Morphology}

General. The lower $17 \mathrm{~km}$. of the Martin River Glacier can be divided into three zones: The Active Ice Zone, the Intermediate Zone and the Terminal Zone (Fig. 3). Both the Intermediate and Active Ice zones are characterized by flowing ice; the two zones are distinguished primarily by the amount of superglacial vegetation present: the Active Ice Zone has little or no vegetation, whereas the Intermediate Zone has abundant vegetation. The Terminal Zone is also veneered by vegetation but is underlain by stagnant or dead ice.

There is very little unanimity regarding the definition of stagnant and dead ice, and in most instances the two terms have been used synonymously to refer to ice that is no longer flowing (Flint 1957, p. 73; Armstrong et al. 1966, p. 13). Bauer (1955, p. 462), termed glaciers flowing slower than $3 \mathrm{~m} . /$ day "stationary" and 
those flowing less than 30m./year "dead". On the basis of his classification, the Active and Intermediate zones of the Martin River Glacier consist of "stationary" ice, and the terminal zone is underlain by "dead" ice.

Sharp (1951, p. 108) summarized "stagnant ice" as being characterized by:

" 1 . heavy cover (of) superglacial debris of ablational origin

2. abundant superglacial ponds

3. deeply incised superglacial streams

4. chaotic superglacial topography

5. decayed condition of ice ... arches, englacial caverns, passages, and tunnels

6. concave transverse profile

7. great vertical shrinkage with little or no terminal recession

8. lack of crevasses."

Generally, Sharp's first four characteristics apply to the Intermediate Zone of the Martin River Glacier, and some arches, caverns, passages and tunnels are also present in this zone. The transverse profile, however, although fairly flat is not concave, and crevasses are present, indicating flowing ice. The criterion of "great vertical shrinkage with little or no terminal recession" cannot be adequately evaluated; there are numerous trimlines and moraines indicating former higher profiles of the glacier, and the terminal moraine is only about $4 \mathrm{~km}$. from the active ice margin, but there are no data on how much deeper the glacier has eroded since those profiles were formed. Sharp (1951) concluded that no single criterion can be used to define or exclude "stagnant ice"; measurements must be made.

The inference is that if the ice is found to be flowing, it is not stagnant. Because the Active and the Intermediate zones of the Martin River Glacier are underlain by flowing ice, they are not stagnant. The ice in the lower $17 \mathrm{~km}$. of the Martin River Glacier flows about $200 \mathrm{~m}$./year, farthest upglacier (Post 1967), and diminishes to zero at the terminus. The boundary between the active (Bauer's "stationary" ice) and the dead ice is beneath "Miller Lake" (Reid and Callender 1965). On the upglacier side of the lake there are numerous small crevasses, whereas on the opposite side exposed ice is scarce and about the only movement is sliding of drift as a result of differential ablation of the buried ice. Along the axis of the lake active compressive flow is responsible for the fact that the lake is enlarging only slowly, despite frequent calving of icebergs from the margins and bottom of the lake. Shearing results in ice flowing into areas where calving has occurred, and calving in turn occurs because of the active shearing there.

The question of just how active the glacier really is was answered by direct measurement. In the summer of 1965 a baseline was established from the "Miller Lake" camp across the outlet stream to the top of a small hill. A third control point was located on the side of the ridge about $2 \mathrm{~km}$. NNW of the other points (Fig. 5, points A, B, and C). From these three points theodolite triangulations were made to cairns and flags on the upglacier side of "Miller Lake". The same stations were again occupied the following year. Fig. 5 shows the results of those surveys. The direction of the displacement of each station shows that the ice is flowing into "Miller Lake" at a rate varying from about $100 \mathrm{~m}$./year (Station 1) to only $33 \mathrm{~m} . /$ year (Station 3). 


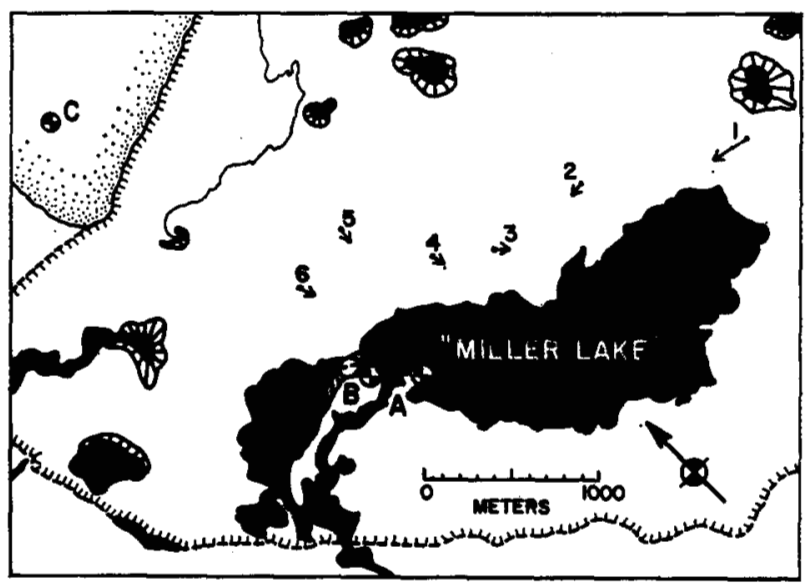

FIG. 5. "Miller Lake" area showing location of base points $A, B$, and $C$, and ice movement stations. Arrows show double the actual ice movement between 1965 and 1966.

Active Ice Zone. This is the largest of the three zones. In the terminal $17 \mathrm{~km}$. it is characterized by both exposed and drift-veneered ice, medial moraines, small crevasses and moulins, numerous superglacial lakes, and little or no associated vegetation (Fig. 3). Meltwater drainage is largely superglacial in the areas of exposed ice, but englacial and subglacial where the ice is drift-covered.

In the terminal $17 \mathrm{~km}$. of the Martin River Glacier - the area included in this report - exposed ice is considerably scarcer than drift-covered ice (Figs. 3 , 4). Crevasses, superglacial meltwater streams and moulins characterize this part of the zone. The crevasses are shallow, but are up to $20 \mathrm{~m}$. wide at the surface as a result of differential ablation. For the most part they are a minor deterrent to travel; the bare ice areas are considerably easier to cross than the drift-covered zones.

Medial moraines up to $30 \mathrm{~m}$. high interrupt these expanses of bare ice. Most of the moraines are segmented and otherwise deformed by ice flow, but deformation on the north side of the glacier is less than on the south side (Fig. 4). All the northern moraines are ice-cored ridges veneered with slightly metamorphosed granodiorite or quartz diorite rubble, whereas the southern moraines are covered with dark slate debris (see tonal variations in Fig. 4). Particle size ranges from quartz and feldspar grains and sand-size slate fragments to blocks up to $15 \mathrm{~m}$. across. Together, this debris forms an insulating blanket often only as thick as the diameter of the surface particles.

Intermediate Zone. The area of the Martin River Glacier that is characterized by actively-flowing ice (albeit slow) and covered by a dense growth of brush and trees is defined as the Intermediate Zone. Fig. 3 delineates the extent of this zone along the margins of the glacier. In most places it is separated from the terminus by a zone of dead ice.

Except for the walls of ice sinkhole depressions (Reid and Clayton 1963; Clayton 1964), exposed ice is scarce at the surface in this zone, most of which is blanketed with superglacial drift ranging in thickness from a fraction of a centimetre to over 2 metres. Thickets of alder and willow or even spruce forests obscure much of the drift surface. This area is most difficult to traverse except for those with exceptional equilibrium and a talent for using a machete. Adding to 
the difficulty of travel through this zone is the fact that differential ablation here increases the intensity of mass movement of the superglacial drift and vegetation, causing large masses of alders and willows to topple and expose their roots. Broken masses of dead branches and roots dumped haphazardly over the surface add to the chaotic appearance of the zone.

In one area, where the Intermediate Zone terminates in a small lake northwest of Charlotte Lake, trees over $25 \mathrm{~m}$. tall and 100 years old grow on only $1.5 \mathrm{~m}$. of superglacial drift (Reid 1969, p. 50). Obviously, this part of the glacier is very stable and could very well be included in the Terminal Zone. Because this ice apparently is still flowing, however, it is included in the Intermediate Zone.

Lakes are also characteristic of the Intermediate Zone. They range from small lakes less than $100 \mathrm{~m}$. in diameter, in conical depressions, to the irregular "Miller Lake", over $2 \mathrm{~km}$. long (Figs. 3, 4). The small lakes are ephemeral features, which may exist for several years as the glacier carries them toward the terminus, or which may suddenly drain and fill again several times in one season (Reid and Clayton 1963). Such lakes may drain when warmer (and therefore denser) surface water is able to circulate and cause bottom melting, thereby releasing the water through subglacial or englacial tunnels. But, Glen (1954, p. 317) suggested that such lakes drain when the "level of the water rises until the pressure at the lowest point exceeds the corresponding ice pressure sufficiently for ice flow to occur". The fact that one specific lake drained after nine days of abnormally warm weather and that the level had been rising at least for 52 days previously, makes it difficult to determine which factor caused the sudden drainage. Blockage of the tunnels by roof collapse or by boulders, may suddenly terminate the drainage. If the drainage system includes several lakes, the lowest ones may fill again to a common hydrostatic level. One such lake drained at an average rate of about 3,800 cubic metres per minute for the 20 minutes it took to drain completely (Reid and Clayton 1963).

The larger and more irregular lakes result from the coalescence of smaller lakes (Figs. 3,4). Comparison of photographs taken in 1938 and since 1950 reveals the rapid evolution of "Miller Lake" near the terminus of the Martin River Glacier (Reid and Callender 1965, Fig. 5). In 1963 this lake was $2.8 \mathrm{~km}$. long and up to $800 \mathrm{~m}$. wide and $70 \mathrm{~m}$. deep; it had an area of $1.59 \mathrm{sq} . \mathrm{km}$. and was ice-walled and at least partly ice-bottomed. The mean depth in 1963 was $25 \mathrm{~m}$. (Callender 1964, p. 27). The lake evolved by the coalescence of numerous small ice sinkhole lakes similar to those described on the Charlotte Lobe $6 \mathrm{~km}$. to the east (Reid and Clayton 1963).

In addition to the continuous roar of superglacial debris sliding and tumbling into "Miller Lake", there are two other notable phenomena: the sudden fluctuations of lake level and the emergence of huge ice masses from the lake bottom.

As part of the 1963 research program, lake levels and meteorological observations were recorded twice each day. Although the lake level always rose following periods of precipitation, in the early morning of 4 July 1963 the lake level rose much more rapidly than was normal, following light rain the night before (Fig. 6). Measurements were made every few minutes until the rate of rise could be determined, then at regular intervals for the next 24 hours. 


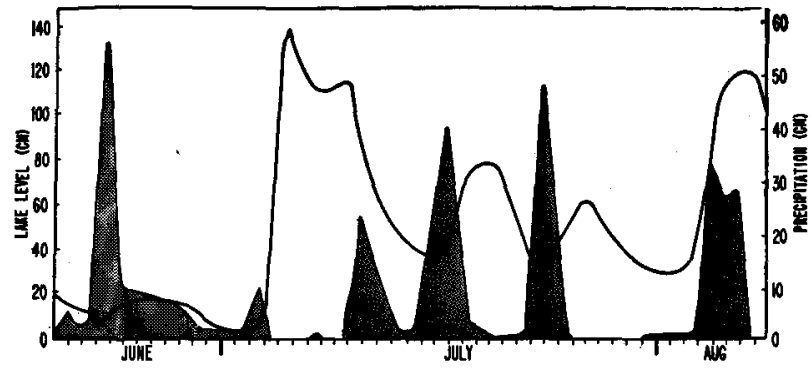

FIG. 6. Relationship between precipitation (shaded graph) and fluctuations of "Miller Lake" surface, summer 1963.

A survey of the lake during this event failed to disclose any sign of a water source; the numerous superglacial streams had neither increased in volume nor gave any evidence of surface turbulence over presumed drainage connections beneath the lake. But the only possible source was one or more englacial or subglacial channels draining a superglacial lake farther upglacier. The exact source could not be located, since more than one of these lakes showed evidence of recent drainage.

"Miller Lake" rose $1.35 \mathrm{~m}$. on $4 \mathrm{July}$; the minimum volume of water represented by the rise was $1,900,000 \mathrm{~m}^{3}$ (502 million gallons or 1,540 acre-feet). This was a minimum volume because the discharge via the only outlet stream (Fig. 5) was so great during the entire time that it could not be measured. However, enough information was obtained to demonstrate that the loss in volume during the subsequent lowering of the lake was considerably greater than could be accounted for by discharge through this outlet stream. Water was therefore also discharging from the lake via another englacial or subglacial route. This flow was probably responsible for a fountain-like discharge that became active at the same time $1.5 \mathrm{~km}$. northwest of "Miller Lake" (shown on Fig. 3 as the head of a river). The total volume represented by the sudden rise on 4 July probably exceeded 3 million cubic metres.

Subsequent measurements of lake levels were made in 1965 and 1966, but no major fluctuations were recorded. When the lake was visited again in June 1968, the level was approximately $15 \mathrm{~m}$. lower than it had been two years before. Study of the exposed zone below the most distinct strandline revealed that the lake had only recently drained, as indicated by 1) stranded icebergs, 2) alder bushes, still green, that had been uprooted by mass-wasting subsequent to lowering of the water table, and 3) negligible integration of drainage across the newly exposed lake muds. The drainage must have occurred within a week of observation.

Further evidence of subsurface drainage was the discovery that the only surface stream channel was high and dry. The lake water must have drained en- or subglacially, probably by the route that controlled the lake during and immediately following the 4 July, 1963 event.

The second striking feature of "Miller Lake" was the frequent release of ice masses from the bottom of the lake (Reid and Callender 1963). Such masses, weighing up to 200 tons, were observed in 1963, 1965, and in 1966. The initial emergence and subsequent bobbing motion caused waves to radiate outward and wash up onto the shore as much as $2 \mathrm{~m}$. above normal lake level. These ice masses demonstrated that the lake was partly, and possibly entirely, ice-bottomed. 
Terminal Zone. The smallest of the three principal zones of the Martin River Glacier is the Terminal Zone, characterized by dead ice and restricted primarily to the area downvalley from "Miller Lake" (Fig. 3). Because the boundary between slowly flowing ice and dead ice is broad and difficult to determine without detailed measurements of ice velocity, the presence of dead ice is identified by two criteria: 1) most of the zone is underlain by ice masses isolated from the main glacier, 2) other parts are defined as stable because of stands of Sitka spruce or the abundance of lichen-covered surface drift. But complete separation of ice masses from the main glacier is difficult to prove without extensive drilling, and spruce stands occur on flowing ice, and lichen-covered boulders are common even in the Active Ice Zone. The extent of the Terminal Zone, as mapped, is conservative.

Surface ice in this zone is restricted to the rare steep slopes where mass wasting has temporarily exposed buried ice. Elsewhere the ice is concealed beneath nonsorted drift whose average thickness probably exceeds $2 \mathrm{~m}$. A pit at site "A" (Fig. 5) reached almost $3 \mathrm{~m}$. without encountering ice, but was abandoned when heavy rains caused mud and rocks to fill the hole. Augering was impossible because of the numerous boulders.

Another feature of this zone is the presence of some clear lakes. In contrast, lakes in the other glacial zones are always milky with glacier flour. Because the clear lakes are sometimes entirely surrounded by ice, either the glacier flour has been filtered out by the thick superglacial drift or else meltwater is no longer a significant contributor to these lakes.

A second pit, to determine drift thickness, was dug in the most active slope of one of these clear lakes near the southern limit of "Miller Lake". The vegetation here was sparse and the drift recently disturbed by mass movement. The glacier ice was reached at a depth of slightly less than $2 \mathrm{~m}$. Immediately above the ice was a layer of water which flowed into the pit with sudden and intermittent spurts up to $30 \mathrm{~cm}$. high. The pressure decreased with time, suggesting that the water had been locally trapped between the ice and the drift. Presumably, most of this water was groundwater recharge from higher upslope.

The minimum drift thickness at this pit was less than $2 \mathrm{~m}$. and the drift was thick enough to protect the lake from the underlying cold ice and thereby permit successful propagation of an abundant fauna (Tuthill 1963).

The vegetation of the Terminal Zone is identical to that of the Intermediate Zone except that spruce trees tend to be slightly larger $(c .60$ to $80 \mathrm{~cm}$. average diameter), and there are open areas beneath some of them. Tree-ring counts of the oldest trees reveal they began to grow about A.D. 1650.

In contrast to the high local relief of the Active Ice and Intermediate Zones (30 to $35 \mathrm{~m}$. in the area of the medial moraines and the ice sinkhole lakes) the maximum relief of the Terminal Zone is only about $20 \mathrm{~m}$. The average relief of the three zones, however, is similar, 15 to $18 \mathrm{~m}$.

Glaciated Zone. The zone formerly covered by glacier ice is characterized by numerous lateral moraines, end moraine segments, and the outermost terminal moraine (Fig. 3). The terminal moraine supports a climax hemlock forest and the vegetative cover masks even the largest of blocks comprising the moraine. But 


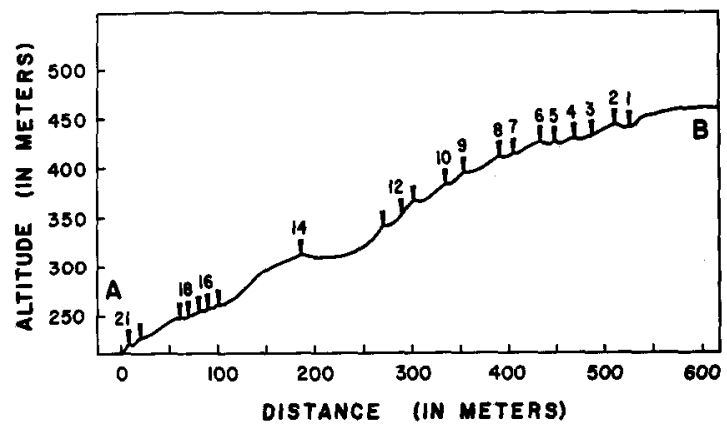

FIG. 7. Profile of the 21 lateral moraines adjacent to the Charlotte Lobe. The profile extends directly upslope from a point $2.2 \mathrm{~km}$. NNW of Charlotte Lake (Fig. 3).

the moraine is not appreciably dissected nor is it buried under outwash sediments.

Trees on the moraine segments, halfway between the terminal moraine and the outer margin of the Terminal Zone, are at least 500 to 600 years old. These segments are sharp-crested and surrounded by outwash deposits, but some large blocks (up to $6 \mathrm{~m}$. diameter) are exposed at the surface. The largest trees are Sitka spruce, but hemlocks are almost as large.

The lateral moraines offer the most conclusive evidence of the age of the end moraines. All lateral moraines converge at or upvalley from the end moraines, supporting the conclusion that the glacier never extended beyond the mapped limit. The youngest lateral moraine (21, Fig. 7) was formed about 1910, as indicated by the age of an ice-shoved spruce in the valley of the Charlotte Lobe (upvalley from Charlotte Lake, Fig. 3). The next youngest moraine apparently was the margin of the active ice about A.D. 1650. The remaining 19 older moraines along the northwest slope of Charlotte Ridge, separating the Charlotte Lobe from the Kushtaka Lobe (upvalley from Kushtaka Lake), are older than 800 years. A distinct change in the degree of soil development at the 7th most recent moraine is interpreted as representing the break between Late Wisconsin age moraines above and Neoglacial moraines below. Geomorphic evidence supports the association of the oldest moraines with both the terminal moraine and the moraine segments, downvalley from the Terminal Zone, and the Neoglacial moraines with the dead ice of the Terminal Zone. Details of the investigations of the Glaciated Zone are presented in another paper (Reid 1970).

\section{SUMMARY}

The Martin River Glacier and its immediate periphery can be divided into 4 zones: Active, Intermediate, Terminal, and Glaciated. The Active Zone is characterized by exposed and superglacial drift-veneered active ice, both contorted and linear medial moraines, crevasses, superglacial streams and moulins, and ice sinkhole lakes. The lower $17 \mathrm{~km}$. of this zone is flowing at a rate of from 200 to about $100 \mathrm{~m}$. per year.

The Intermediate Zone is also underlain by flowing ice, but is characterized by a dense vegetation cover. Superglacial drift here may be as much as $3 \mathrm{~m}$. thick. The numerous ice sinkhole lakes drain frequently via englacial or subglacial channels. 
The area underlain by dead ice is defined as the Terminal Zone. The drift burying the ice masses may exceed $3 \mathrm{~m}$. in thickness. Stands of Sitka spruce have more open areas beneath them than those in the Intermediate Zone and some of the numerous lakes are clear rather than all being milky. This zone was active about A.D. 1650.

The terminal moraine and the numerous moraine segments are all probably of Late Wisconsin age. These, plus the lateral moraines, delineate the Glaciated Zone. Of the 21 successive lateral moraines in the valley of the Charlotte Lobe the 7 lowest are of Neoglacial age.

\section{ACKNOWLEDGEMENTS}

The field research for this report was supported by the National Science Foundation (Grants G22016 and GP-4448). Most of this was written while on sabbatical leave from the University of North Dakota. I am greatly indebted to Dr. A. Lincoln Washburn, Director, Quaternary Research Center, University of Washington, and Dr. John T. Whetten, Chairman, Department of Geological Sciences, for their many kindnesses, particularly for making their entire facilities available to me. Dr. Washburn critically read the manuscript and made many valuable suggestions toward improving it. This report would not have been possible without the wholehearted cooperation of the following co-workers: A. Kirth Erickson, Kent A. Johnson, Frank J. Schulte, and John R. Tinker. I greatly appreciate their cooperation.

\section{REFERENCES}

ARMSTRONG, T., B. ROBERTS and C. SWITHINBANK. 1966. Illustrated glossary of snow and ice. Scott Polar Research Institute, Special Publication No, 4, 60 pp.

BAUER, A. 1955. The balance of the Greenland ice sheet. Journal of Glaciology, 2: 456-62.

CALLENDER, E. 1964. The physical limnology and sedimentology of Miller Lake, Martin River Glacier, South-Central Alaska. Unpublished M.S. thesis, University of North Dakota, $139 \mathrm{pp}$.

CLAYTON, L. 1964. Karst topography on stagnant glaciers. Journal of Glaciology, 5: 107-12.

FLINT, R. F. 1957. Glacial and Pleistocene Geology. New York: John Wiley \& Sons, Inc., $553 \mathrm{pp}$.

GLEN, J. W. 1954. The stability of ice-dammed lakes and other water-filled holes in glaciers. Journal of Glaciology, 2: 316-18.

GRANTZ, A., G. PLAFKer and R. KACHADOoRIAN. 1964. Alaska's Good Friday Earthquake, March 27, 1964. U.S. Geological Survey Circular 491, 35 pp.

HARTSHORN, J. H. 1952. Superglacial and proglacial geology of the Malaspina Glacier, Alaska, and its bearing on glacial features of New England. (Abstract) Geological Society of America, Bulletin, 63: 1259-60.

KACHADOORIAN, R. 1960. Engineering geology of the Katalla area, Alaska. U.S. Geological Survey. Miscellaneous Geological Investigations Map I-308.

MARTIN, G. c. 1908. Geology and mineral resources of the Controller Bay region, Alaska. U.S. Geological Survey Bulletin, 335, $141 \mathrm{pp}$.

PLAFKer, G. 1967. Geologic map of the Gulf of Alaska Tertiary Province, Alaska. U.S. Geological Survey. Miscellaneous Geological Investigations Map I-308.

PLAFKER, G. and E. J. MILLER. 1957. Glacial features and surficial deposits of the Malaspina district, Alaska. U.S. Geological Survey, Preliminary Report, 13 pp. 
POST, A. 1965. Alaskan glaciers: recent observations in respect to the earthquake-advance theory. Science, 148: 366-68.

1967. Non-earthquake origin of supraglacial debris on Martin River and Sioux Glaciers, Alaska. Journal of Glaciology, 6: 953-56.

RAGLE, R. H., J. E. SATER and W. O. FIELD JR. 1965. Effects of the 1964 Alaskan earthquake on glaciers and related features. Arctic Institute of North America, Research Paper 32, $44 \mathrm{pp}$.

REID, J. R. 1969. Glaciers: living and dead. North Dakota Academy of Science Proceedings 1967, 21: 42-56.

1970. Late Wisconsin and Neoglacial history of the Martin River Glacier, Alaska. Geological Society of America, Bulletin, in press.

RED, J. R. and E. CALLENDER. 1965. Origin of debris-covered icebergs and mode of flow of ice into Miller Lake, Martin River Glacier, Alaska. Journal of Glaciology, 5: 497-503.

REID, J. R. and L. CLAYTON. 1963. Observations of rapid fluctuations of ice sinkhole lake levels, Martin River Glacier, Alaska. Journal of Glaciology, 4: 650-52.

SHARP, R. P. 1949. Studies of superglacial debris on valley glaciers. American Journal of Science, 247: 289-315.

1951. Glacial history of Wolf Creek, St. Elias Range, Canada. Journal of Geology, 59: 97-117.

STEPHENS, F. R. 1969. A forest ecosystem on a glacier in Alaska. Arctic, 22: 441-44.

TARR, R. S. and L. MARTIN. 1914. Alaskan glacier studies. National Geographical Society, $498 \mathrm{pp}$.

TUTHLL, S. J. 1963. Preliminary report on the molluscan fauna of the Martin River Glacier and associated area (south-central Alaska). The Veliger, 6: 84-90.

1969. Earthquake-triggered rock avalanches and glacial stagnation in southcentral Alaska, in The great Alaska earthquake of 1964. Hydrology Volume, National Academy of Science Publication, 1603: 362-68.

TUTHILL, S. J. and w. M. LAIRD. 1966. Geomorphic effects of the earthquake of March 27, 1964 in the Martin-Bering Rivers area, Alaska. U.S. Geological Survey Professional Paper 543-B.

WAHRHAFTIG, c. 1965 . Physiographic divisions of Alaska. U.S. Geological Survey Professional Paper 482, 52 pp. 6 plates. 